\title{
Bellman og det heibergske hus
}

af lektorvikar, mag.art. Lise Busk-Jensen

I litterære kredse beklages det ofte, at to nabofolk som danskerne og svenskerne tilsyneladende ikke interesserer sig særligt for at lære hinandens litteraturer at kende, skønt vi så udmærket kan forstå hinandens sprog, når det drejer sig om f.eks. grænsehandel eller ferierejser. Vi danskere må da også for vort vedkommende erkende, at kun et fåtal af Sveriges store forfattere gennem tiden er nået ud til en større dansk læserkreds, ligesom danske forfattere heller ikke i udpræget grad har ladet sig inspirere af deres svenske kolleger.

Man kan dog pege på enkelte undtagelser, f.eks. Strindberg og Lagerlöf og for børnelitteraturens vedkommende Astrid Lindgren; det mest oplagte eksempel er imidlertid Bellman, som danskerne umiddelbart tog til sig, og hvis kulturelle indflydelse her i landet egentlig er uden sidestykke. Endnu i dag, 200 år efter hans død, kender de fleste danskere viser som „Vila vid denne källa“, „Gubben Noach“, „Fjäriln vingad syns på Haga“; dertil kommer de mange melodier, som vi har lært at kende via Bellman, uden at vi måske gør os det klart.

Ved nærmere eftersyn viser den danske Bellman-interesse sig i øvrigt at udgå fra et bestemt centrum, nemlig Heiberg-familien. Denne familie spillede som bekendt i næsten 100 år, fra 1790'erne og til det moderne gennembrud, en hovedrolle i dansk åndsliv og må betegnes som en af dansk kulturs mest grundfæstede institutioner. Først var Bellman inspirationen bag Peter Andreas Heibergs klubviser; dernæst var han inspirationen bag en vigtig side af Heibergs hustru, romanforfatteren Thomasine Gyllembourgs litteratur- og livssyn; så inspirerede han parrets søn, digteren og teaterdirektøren Johan Ludvig Heibergs vaudeviller; og endelig var han en 
væsentlig inspirationen for Johan Ludvigs hustru, skuespillerinden Johanne Luise Heiberg i hendes arbejde med at udforme sin kunstnerpersonlighed.

Der var altså god grund til at mindes Bellman på 200 års dødsdagen d. 11. februar 1995, men der er lige så god grund til at spørge, således som jeg har tænkt at gøre i det følgende, hvad det egentlig var ved Bellmans kunst, som i den grad åbnede Danmarks litterære scene og det kulturbærende Heibergske hjem for ham.

\section{Bellman og Fredman}

Faktisk er det slet ikke indlysende, at den sensuelle, vin- og kvindeglade, folkelige skjald Bellman skulle blive så vel modtaget i det intellektuelt forfinede, borgerlige og positionsbevidste Heibergske hjem. For at udrede nogle af trådene i denne usædvanlige alliance er jeg nødt til indledningsvis at give en karakteristik af Bellmans kunst. Pladsen tillader naturligvis ikke nogen form for fyldestgørende fremstilling, så jeg vil holde mig til tre træk, som forekommer mig at være de væsentligste i denne sammenhæng, idet de kan bidrage til at forklare Heiberg-familiens begejstring for den svenske digter.

Det første træk, jeg vil pege på, er de bellmanske sanges karakter af små dramatiske situationer. Jeg tænker naturligvis især på Fredmans Epistler, der udkom i 1790. Her møder vi flere typiske personligheder i genkendelige stockholmske lokaliteter.

I midten står den forulykkede urmager Fredman, som hellere vil være sammen med vennerne på værtshuset end hjemme hos sin stride kone. Han er en mangesidig personlighed præget af både lys optimisme og sort pessimisme, af en kraftig livsdrift og en lige så stærk lyst til at gå i hundene, skiftevis sprængfyldt af glæde og tynget af grublende mismod. Han er også Bellmans alter ego. Hans hjerteveninde hedder Ulla Winblad, en letlevende hav- og skovnymfe, „præstinde i Bacchi tempel“, som det siges, kvindelighedens og erotikkens repræsentant. Blandt Fredmans venner ses Mollberg, forhenværende velsitueret fabriksejer, nu korporal, festarrangør, dansemester og slagsbror. Desuden Moviz, parykmager, konstabel og basviolspiller, og fader Berg, tapetserer og virtuos på flere instrumenter.

Denne flok og flere til samles på værtshuse som Gröna Lund, på udflugter til Djurgården eller på byens torve og pladser, og her underholder de sig selv og hinanden med musik og dans, med at drikke og synge. Hver enkelt sang handler om en bestemt episode i deres burleske liv og tegner samtidig et billede af socialitet og 


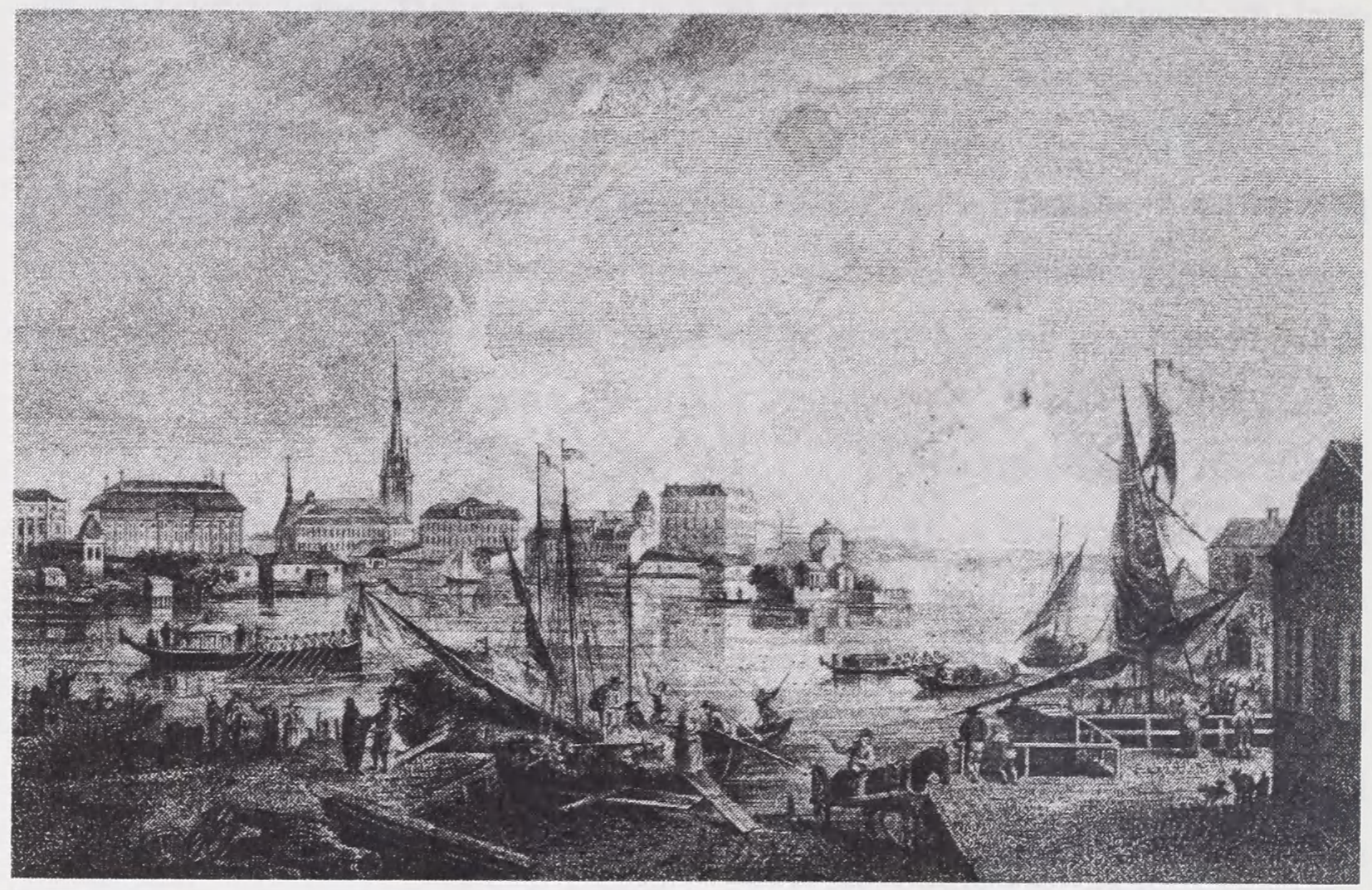

Udsigt mod Stockholm. Litografi fra ca. 1800.

menneskelighed på randen af det sene 1700-tals borgerlige svenske samfund.

Det andet træk, jeg vil nævne, drejer sig om musikken til digtene. Som bekendt lånte Bellman flertallet af sine melodier fra den store franske chansontradition. Det havde i Frankrig længe været skik at genbruge visemelodier, melodier til gadeviser, selskabssange, danse- og drikkeviser. Melodiens kendte sammenhæng, f.eks. en drikkevise, stod da i en spændingsfyldt kontrast til det nye indhold, f.eks. en kærlighedsduet, hvilket opfattedes som muntert parodisk. Parodien er et fremtrædende element i Bellmans digte; med sine viser om Bacchi Tempel parodierede han tidens mange frimurerloger, og de græske guder er ofte parodisk tilstede mellem de jævne stockholmske drikkebrødre og hjerteveninder.

Sammenbragte vers og melodier med små stumper af dialog imellem havde floreret på de franske teatre siden Ludvig 14.'s tid under betegnelsen vaudeviller, en let forvanskning af navnet på deres oprindelsessted Val de Vire, viredale; også Stockholm havde sin scene for syngespil. Vaudevillen kan betragtes som modstykket til det strengt stiladskilte officielle teater, hvor man enten hørte musik eller dialog, enten var til opera eller til drama; blandingen af tragedie og komedie ansås for at være et brud på den gode smag. Vaudevillegenren opstod faktisk som et resultat af 
de officielle teatres monopol på den rene opera og det rene drama. Det var en folkelig genre, hvis sange ofte havde den moderne revyvises aktuelle karakter, og en genre som fik stærk medvind i de demokratiske tider under den franske revolution.

Vaudevillens sange opfyldte det musikalske behov i tidens nye kulturelle miljøer. Melodierne kunne bruges til fællessange i de politiske diskussionsklubber; man kunne underholde med dem i storbyernes værtshuse og gader, som nu afløste tidligere tiders markedspladser, og den voksende middelklasse kunne bruge dem hjemme i den intime sfære, hvor de enkelte familiemedlemmer kunne spille dem til personlig fornøjelse for siden at underholde med dem i vennekredsen.

Det tredje og sidste træk, jeg vil anføre, fremhæves med rette af alle Bellmandyrkere, nemlig hans tætte sammenhæng mellem tekst og musik. Hvis ordene og tonerne ikke i sig selv er så mærkværdige, så gør deres kunstfærdige forening og gensidige betingethed helheden til noget enestående. Tekstens ord er fra begyndelsen tænkt sammen med melodiens forløb, instrumenternes egenart og tonernes rytme. Musikken realiserer ordene og omvendt på en unik måde. Hvis teksten fortæller, at fader Berg støder i hornet, så former rim og syntaks en sproglig rytme magen til hornets, og melodiens taktslag gentager hornets trutten.

Sammensmeltningen af musik og tekst, af indhold og form, sikrer de Bellmanske scenerier deres troværdighed. Den er også forudsætningen for, at det lykkes ham at forene mytologiske figurer med stockholmske svirebrødre og at fastholde et barnligt-naiv blik på det ofte rå og forhutlede miljø. De grelle kontraster ophæves i en legende og elegant stil og i et livssyn, som forbinder Bellman med den samtidige rokoko. Selvfølelsen og de romantiske naturscenerier med udflugter på vandet, måneklare nætter og stjerneglans over sneen peger samtidig frem mod 1800-tallets romantik.

\section{Bellman og den første Heiberg-generation}

I 1780'erne kendte man ikke Bellmans navn i København, men nok hans sange. Fredmans epistel nr. 9, „Käraste Bröder, Systrar och Vänner“, var udkommet som skillingstryk i 1782 og solgt i flere oplag. Det samme gjaldt et par andre epistler (nr. 23 og 35). De er formentlig bragt med af tilrejsende fra Sverige, som også har kunnet melodierne, for melodierne blev kendte, skønt de ikke var med på trykket ${ }^{0}$. Baggesen skrev i 1783 et par drikkeviser til epistel nr. 9's melodi, og Peter Andreas 
Heiberg oversatte epistel nr. 56 til dansk ${ }^{1}$.

Bellmans sange var altså velkendte, men teksterne var ikke agtede i de litterære kredse. Man lånte gerne musikken, men satte hellere nye ord til. Det gælder P.A. Heibergs kendte politiske vise „Vor Klub er dog en herlig Sag“ fra 1794, som kun havde musikken fra Bellman ${ }^{2}$. Rahbek fortæller i sine erindringer, at han begyndte at skrive drikkeviser for at frembringe noget bedre i betydningen mere højstemt, mere anakreontisk end „Käraste Bröder ...“3. Både P.A. Heiberg og Rahbek var ivrige klubmedlemmer og har nok ikke brudt sig om Bellmans parodiske fremstilling af ordensvæsenet i den gruppe sange, der er samlet i Bacchi Tempel (1783).

Oluf Friis skriver ${ }^{4}$, at man dyrkede Bellman i Thomasine Gyllembourgs barndomshjem i Nyhavn hos dispachør Johan Buntzen i 1780 'erne. Thomasines og hendes søstre fik en omhyggelig musikalsk opdragelse. Fra 1789 var Weyse deres lærer i musik, og han vedblev at komme i Thomasines hjem, også efter at hun var blevet gift med først P.A. Heiberg og siden den svenske friherre Carl Frederik Gyllembourg-Ehrensvärd.

Erindringerne fra samtiden fortæller om, hvilken rolle amatørmusikken spillede i det daglige liv. Sophie Thalbitzer, som kendte Thomasine fra før giftermålet med Heiberg i 1790, skriver:

„Jeg havde kiendt Madame Heiberg i mine yngre Aar. Hun fornyede nu Bekiendtskabet, og vi vare gierne sammen engang om Ugen, enten hos mig eller hos hende. Hvor mange moersomme Aftener har jeg ikke tilbragt der! Hun var meget musikalsk, og naar vi havde spilt og siungen, kom Heiberg sommetider ind og læste høit for os, hvad han havde skreven. Hvor hiertelig har jeg ikke leet over „Virtuosen", som jeg første Gang læste der."5

Virtuosen var blot en af de mange komedier og syngespil, som Heiberg skrev i disse år, og som sammen med Bellmans viser er blandt forudsætningerne for sønnen Johan Ludvig Heibergs vaudeviller.

Sophie Thalbitzer skriver videre: „En Aften, jeg besøgte Mad. Heiberg, bragte hendes Mand de franske Commissairer og den hollandske og franske Minister hiem med sig“. Tiden er her 1793, midt i den voldsomste del af den franske revolutions periode. Det nye franske styre sendte gesandter til København, og de blev vel modtaget af den frisindede del af det danske borgerskab, i særdeleshed af Heiberg. Efter bordet delte selskabet sig, og Sophie Thalbitzer husker, at Thomasine og hun selv 
foretrak musikken for kortspillet: „Vi tilbragte den øvrige Deel af Aftenen ved Claveeret med Duveyrier, Grouvelle og Huygens, som ikke spilte Kort"6. Vi ved, at franskmændene sang deres sange for de danske damer, specielt „Marseillaisen“, og at de efter sådanne selskaber sendte noderne som takkegave. Hvis Thomasine har kendt Bellman siden sin barndom, er det sandsynligt, at hun sammen med Sophie har gengældt franskmændenes opmærksomhed og sunget Bellman for dem.

Desværre var P.A. Heibergs og Thomasines hjem langt fra altid præget af den

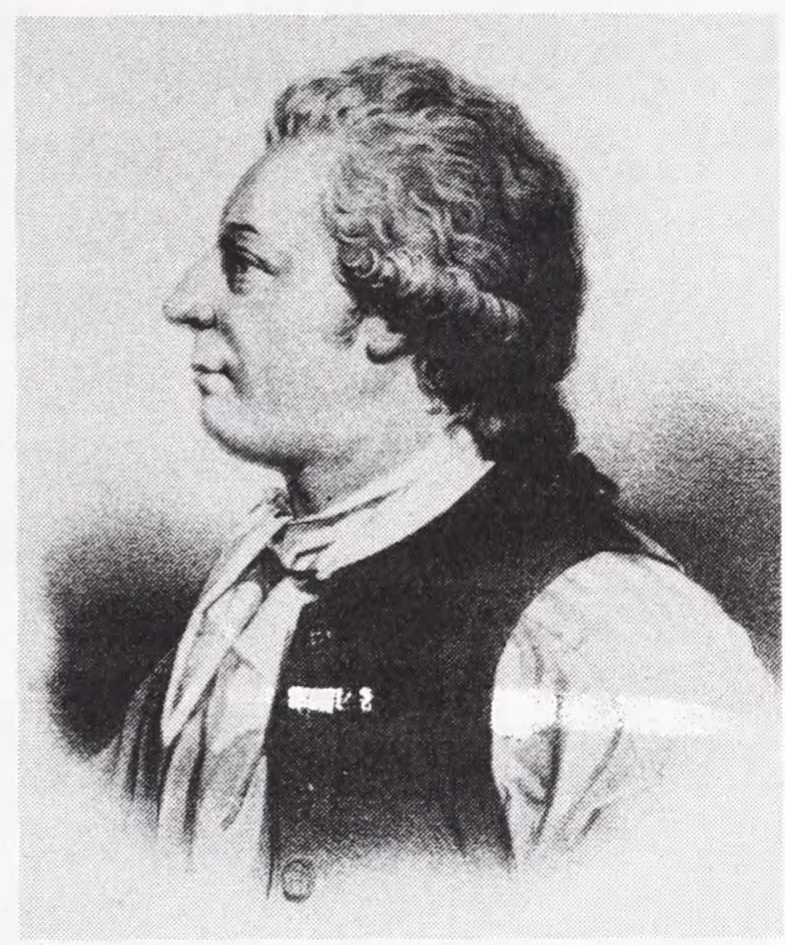

Carl Michael Bellman ( 1740-95). her beskrevne muntre selskabelighed. Han blev stadig mere optaget af sine politiske fejder mod den enevældige administration, og Thomasine, der tappert havde holdt stand mod de lidenskabeligt kurtiserende franskmænd, måtte overgive sig til den mere stilfærdige, men ømt-omsorgsfulde svensker Gyllembourg. Han var blevet landsforvist til København efter en dom for meddelagtighed i planlægningen af mordet på Bellmans velgører Gustav III. Medens Heiberg var i klubben, tilbragte Gyllembourg aftenen alene med Thomasine og hendes syvårige søn. Thomasines svigerdatter, Johanne Luise Heiberg, har beskrevet disse aftener i sin bog om svigerforældrene. Gyllembourg fortalte så levende om livet på de svenske herregårde, at „ikke blot Heibergs Hustru lyttede med spændt opmærksomhed, men ogsaa den lille Johan Ludvig standsede sine Lege for at være tredie Mand i det hyggelige lille Aftenselskab. Man læste høit, man sang og spillede for hinanden, og Timerne fløi som Minuter"7. Det er nærliggende at tro, at Bellmans sange har været på det lille selskabs repertoire. Gyllembourg må have kendt dem i et langt større tal end Thomasine, og mon ikke han har inkluderet netop dem i den kulturelle bagage fra sit fødeland, som han var ivrig efter at gøre sin nye veninde bekendt med ${ }^{8}$.

Det forfatterskab, Thomasine Gyllembourg langt senere frembragte, bærer spor af alle hendes væsentlige livserfaringer, herunder også den erfaring at uudtalte og forbudte følelser mellem elskende kan kommunikeres igennem musikken. 


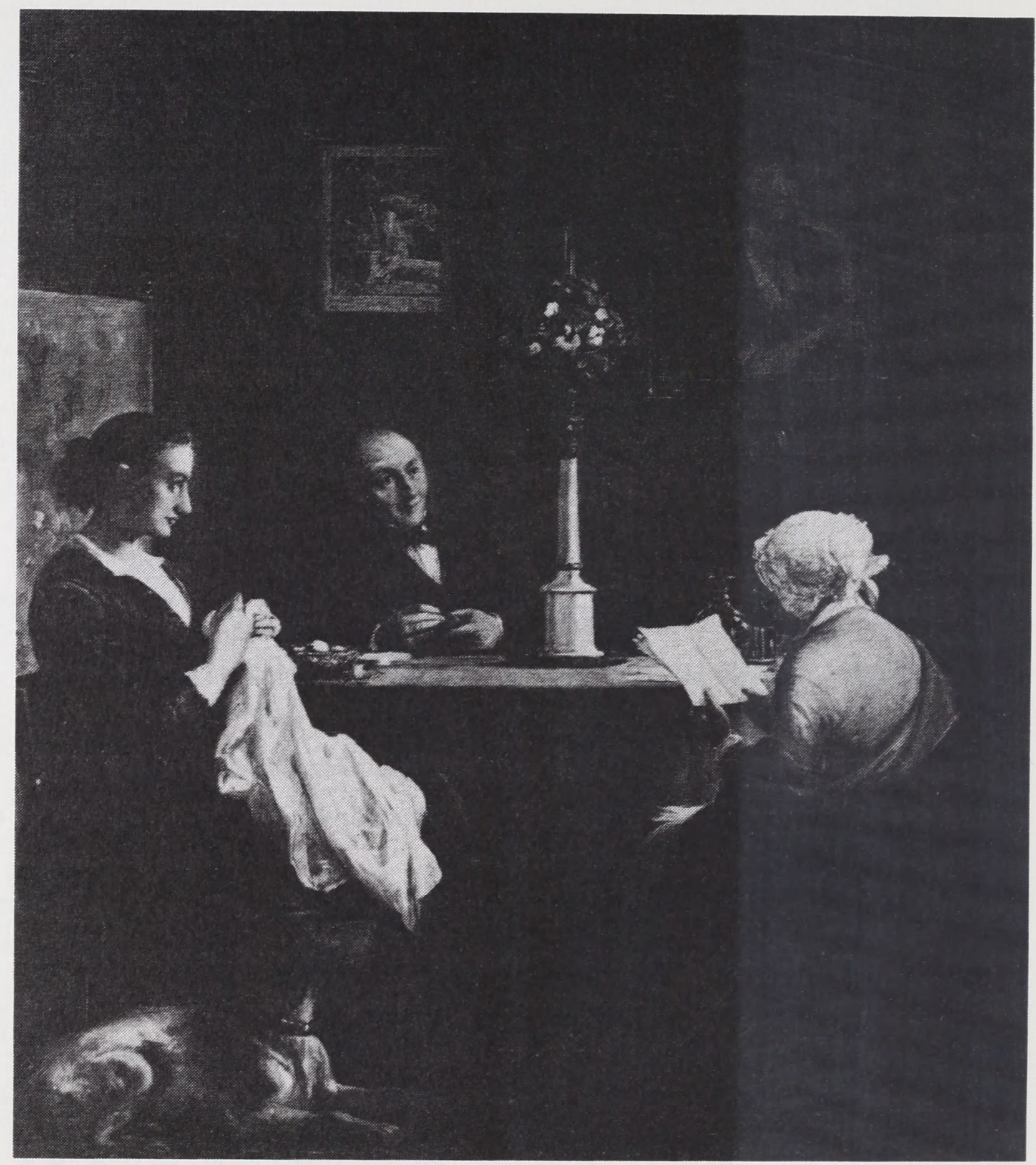

Ægteparret Johanne Luise og Johan Ludvig Heibergs hjem. Fru Thomasine Gyllembourg oplæser en novelle. Efter maleri af W. Marstrand.

I romanen Agtestand fra 1835 beskriver hun den slags hjemmeaftener fyldt af musik, som hun selv havde kendt, dels i selskab med de franske udsendinge, dels med Gyllembourg. I romanen er Sophie gift med en ældre mand, som ikke nærer særlig varme følelser for sin kone og slet ikke bryder sig om at vise dem, han trods alt har. Han er utvivlsomt et billede på Heiberg. Sophie får nu, som i sin tid Thomasine, en erstatning i en franske gesandt, Sardes hedder han her. Til gengæld har hun en lillesøster, Annette, som chaperone, for at læserne ikke skulle tage anstød. Sce- 
nen beskrives i romanen således:

„Ofte udførte [Sardes] ogsaa med Annette Duetter for Guitar og Pianoforte; ofte sang de med hinanden. Sophie sad da fordetmeste ved Siden, lidt tilbage, og medens Annette glædede sig over den Begeistring, hvormed den elskværdige Sanger foredrog de erotiske Toner og Ord, som hun tilegnede sig, og optog i sit Hjerte, bøiede Denne sig ubemærket imod Sophie, fæstede sine forelskede Blikke paa hende, og henvendte hvert Ord, hver Tone til hende."9

Thomasine var, som det var almindeligt for en kvinde med hendes baggrund, temmelig religiøs og optaget af at leve op til sine moralske normer. Det lille citat viser imidlertid, at hendes musikalske repertoire udmærket kunne omfatte erotiske viser. Den side af Bellmans sange har således ikke virket skræmmende på hende.

Man må jo ellers spørge sig selv, hvordan det var muligt, at Fredmans lystige epistler kunne finde vej til Thomasines anstændige dagligstue. Kunne Thomasine f.eks. genkende sig selv i Ulla Winblad? Mit svar er: Både ja og nej.

Thomasine Gyllembourg måtte naturligvis stå meget fremmed for de forskellige udskejelser og den sociale degradering, som gemmer sig i Bellmans beskrivelse af brødrene og søstrene i 'Bacchi Tempel'. Den letlevende Ulla, som gavmildt giver de mange del i sin person, havde ingen plads i hendes univers. Til gengæld kunne hun fuldt ud goutere den høviske og galante tone hos Bellman og hele livsglædens erotiske fylde. Når kroejeren i epistel 36 beundrer Ulla under morgentoilettet, mens hun „För Spegeln [...] stänkte sin barm / Med vin och rosen-vatten“10, så han glemmer alt om sine forretninger, svarer det ganske til Thomasines mening om, hvilken plads kvinden bør indtage i enhver mands liv. Hun har givetvis forstået Bellman, netop som han ønskede at blive forstået. Hun har ikke forsøgt at løfte det barnlighedens og naivitetens slør, som han kastede over sine forhutlede eksistenser. Bellmans evne til at forskønne det dagligliv, som kan være tungt nok at bære, hans evne til at se det livsbekræftende og talentfulde i de mest forskelligartede mennesketyper, har Thomasine sat pris på.

Dertil kommer, at Thomasine Gyllembourg har overtaget Bellmans æstetiske credo: den tætte forening af ord og toner. I hendes bedst kendte fortælling, En Hverdags-Historie, kontrasteres to kvindetyper, den overfladiske københavnerpige, Jette, som helten er så uheldig at forlove sig med, og den ideale Maja, som det trods alt lykkes ham at få til sidst. Til Majas ideale kvaliteter hører hendes måde at musi- 
cere på. Om Jette hedder det, at hun: „spillede meget sværere Sager, og havde langt større Færdighed end Maja“, men Maja forstår til gengæld den kunst at skabe en perfekt harmoni af stemme og musik. Fortælleren siger om Maja:

„Hun sang aldrig andet end Romancer og smaa Sange, hvortil hun accompagnerede sig selv paa Pianofortet. - I ældre fransk Poesie støder man ofte paa den Talemaade: „marier sa voix au son de la lyre“. - Nu først var Meningen heraf mig klar, thi Maja forstod saaledes at lempe Instrumentet efter sin Sang, at det lød, som om den inderligste Forening sammenbandt dem." 11

Jeg tror ikke, at det er tilfældigt, at denne Maja er svensk. Thomasine Gyllembourg var meget bevidst om de kilder, hun øste af ${ }^{12}$.

\section{Bellman og den anden Heiberg-generation}

Efter al sandsynlighed har Johan Ludvig Heiberg således kendt Bellman fra sine tidligste år. Han har som barn hørt moderen spille og synge viserne i det Heibergske hjem, og som ung mand har han og vennen Weyse dyrket Bellman i det Gyllembourgske hjem. Ydermere fik han tidligt en direkte forbindelse med Sverige, idet han i 1812 opholdt sig nogle måneder i Stockholm hos slægtninge af Gyllembourg, og man må formode, at det har bestyrket kendskabet til Bellman.

I alt fald fortæller Hauch i sine erindringer, at Heiberg underviste ham i guitarspil, mens de begge opholdt sig i Paris, Heiberg på et flerårigt besøg hos sin landsforviste far. Hauch skriver:

„Han var den Første, der gav mig Underviisning i Guitarspil, han var ogsaa den Første, der gjorde mig opmærksom paa Bellmans Sange, og efter min Anmodning nedskrev han flere af Melodierne dertil, som jeg ofte har spillet og fundet Trøst i siden [...] Enkelte Gange, naar jeg ikke befandt mig vel, kom han til mig, og gik ikke bort, før han havde bragt mig til at glemme min Sygdom med sin sang og sit Guitarspil. Det var især Bellmans Sange, som han spillede"13.

Heiberg hævdede altid, at inspirationen bag hans vaudeviller i lige så høj grad var Bellman som den franske vaudevilletradition, han havde lært at kende under pariseropholdet. Hauchs erindringer viser $i$ alt fald, at Bellman stadig var i hans tanker.

Heibergs vaudeviller trak i årtier fulde huse på Det kgl. Teater og fik langvarig indflydelse på dansk kultur i det hele taget. Det første, han skrev i genren, var de 
såkaldte Børnevaudeviller fra 1826. Det er en lille dramatisk digtcyklus med indlagte sange. Formelt set minder de mest af alt om Fredmans epistler, men Heiberg lånte også motiver hos Bellman; et af digtene hedder „Dyrehavsreisen“ og skildrer en udflugt til Bakken, hvor man finder netop den natur, som Bellman foretrak, naturen som ramme om et folkeligt forlystelsessted.

Dyrehavsbakken satte igen scenen i en af Heibergs rigtige vaudeviller, Recensenten og Dyret fra september 1826, men Aprilsnarrene fra april samme år foregår i en lokalitet så fjernt som muligt fra Bellmans, nemlig i et pigeinstitut. Heiberg lånte mange af Bellmans melodier til den række vaudeviller, han skrev de følgende ti år, men stykkernes temaer holdt sig naturligt nok stadig tættere til den københavnske dagligdag, som Heiberg var fortrolig med, og som nu efterhånden var kommet på et halvt århundredes afstand af Bellmans tid.

Skønt publikum valfartede til Heibergs vaudeviller, og billetterne blev solgt til dobbelt pris på den sorte børs, frygtede mange af kulturlivets støtter, at teatret ved at spille stykker i denne genre, som Rahbek skrev, skulle rykke „Fieleboden nærmere"14. Heiberg blev angrebet fra flere sider, men han havde svar på rede hånd. Han udgav et 100 sider stort forsvarsskrift for vaudevillen, hvori det til slut hedder:

„Jeg har ogsaa i [Recensenten og Dyret] begyndt at efterligne det bellmanske Mønster, thi Bellmans saakaldte Epistler ere at betragte som Vaudeviller udenfor Theatret. Det, som characteriserer dem, er en forunderlig Blanding af det Burleske og det Melancholske, hvilket Sidste frembringes ved en besynderlig, Længsel vækkende Maade, hvorpaa Digteren beskriver Localiteter og Naturscener" 15.

Heiberg siger her, at han både har lært af Bellmans form ved at se Epistlerne som teaterstykker, og af hans særlige stilblanding og stemning. Bellmans tidsbestemte typer og lokaliteter er derimod nu sunket ned under horisonten.

En anden vigtig forudsætning for Heibergs vaudeviller var mødet med den unge skuespillerinde Johanne Luise Pätges. Hun var, da de mødtes, kun 13 år gammel, sky og indvendt, beskeden og overfølsom på grund af sin baggrund som barn af fattige indvandrere. Heiberg så hende straks som ingenuen i sine stykker og idealkvinden i sit liv. Efter en passende tid friede han, og de blev gift i 1831. Dette valg af kvindetype understreger måske tydeligst afstanden til Bellman. Jomfru Pätges var meget langt fra nogen Ulla Winblad. Hun var snarere en alf end en nymfe, en luftånd som værnede om sit vingestøv, så hun kunne holde sig svævende. 
Ikke desto mindre dyrkede ægteparret Bellman intenst under deres første sommerferie sammen i 1832, som de tilbragte i Hørsholm og siden kaldte Bellmansommeren. Fru Heiberg fortæller herom i sine erindringer:

„Heiberg havde i mange aar været en stor Beundrer af den svenske Digter Bellmans henrivende Sange. Mig havde han Vinteren iforveien lært at læse og synge denne i Lune og Gratie enestaaende Digters Frembringelser, saa jeg kunde en og hver af hans Sange udenad. "16

Det indgående kendskab til Bellmans digtning blev en vigtig forudsætning for den stadig rigere kunstnerpersonlighed, Johanne Luise Heiberg udfoldede.

Med i Hørsholm var digteren Henrik Hertz, som både var forelsket i den nygifte frue og i hendes Bellman-fortolkning; „vi sang dem for Hertz“, skriver Johanne Luise videre samme sted, og „han blev så henrevet af deres Skjønhed og saa begjærlig efter at kjende dem alle, at han med ustandselig Iver opfordrede mig til atter og atter at synge dem for ham."

Til minde om denne sommer skrev Hertz digtet Posthuset i Hirschholm på melodien til Fredmans epistel nr. 77, den samme epistel som digteren hører i strofe 5 og 6, som jeg her vil citere:

„End af en Skorsteen derovre sig hæver

Som et Slør af Æther den blaalige Røg,

Lyser i Maanskin, imedens den svæver

Bølgende forbi den beskyggede Bøg.

Og med et Shawl om det lokkede Haar

Viser sig En i vor øverste Stue:

Lænet til Armen i Vinduet staaer

Eensom professorens Frue.

Hør, hvor hun synger: „See, skyarna glimma,

Stjernonra forsilfra båd vatten och land,

Månan i molnet sin gulgula dimma

Kaster öfver klappträn och såar vid strand."

Fredman! Din Sang, der er kjendt af saa Faa,

I hendes drømmende Tanke den hviler;

Ak! Og i Øinenes natdunkle Blaa

Speiler sig Maanen og - smiler." 17 
Således kom Bellman til at spille en hovedrolle for to generationer af det Heibergske hus. Han er medspiller i trekanten mellem først P.A. Heiberg, Thomasine og Gyllembourg og 40 år senere mellem J.L. Heiberg, Johanne Luise og Hertz. Da disse mennesker tegnede en stor del af dansk kulturliv, sørgede de for, at Bellman kom med i billedet.

\section{Bellman og Danmark}

„Fredman! Din Sang, der er kjendt af saa Faa", skrev Hertz, men som vi har set, var det en sandhed med modifikationer, og det skulle det vise sig at blive i endnu højere grad i de efterfølgende år. Danske digtere

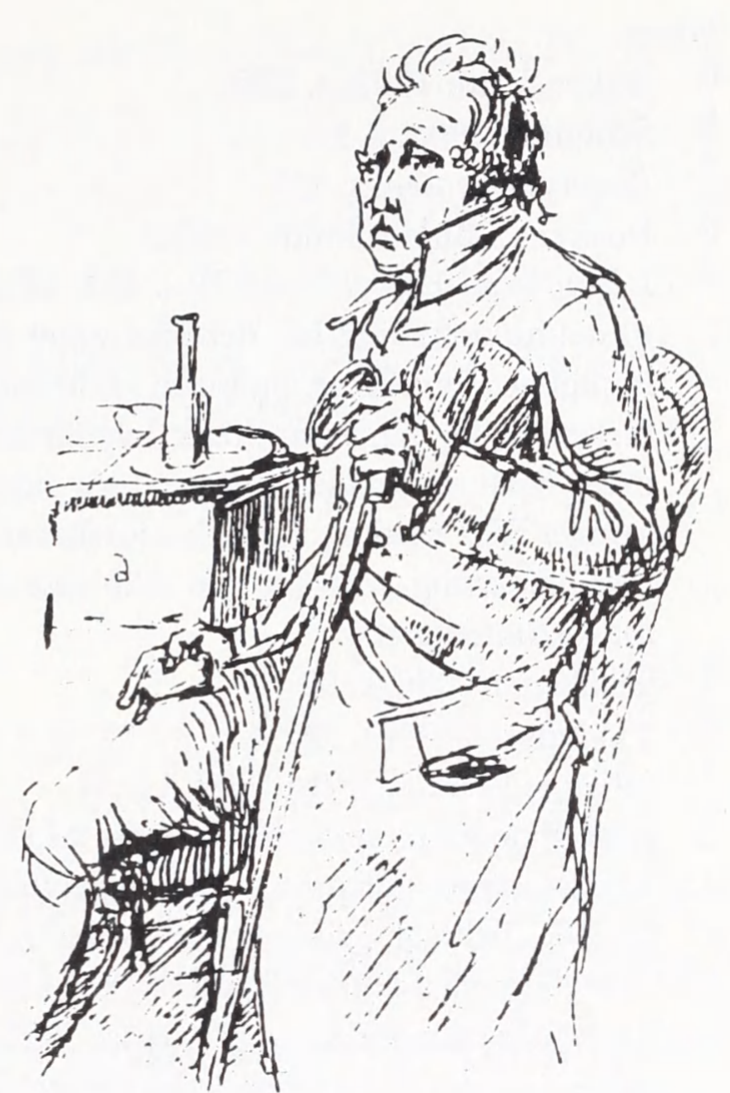

Bellman ved morgenbordet. Tegning af Johan Tobias Sergel.

lod sig nemlig fortsat inspirere af Bellman, og når de fleste danskere i dag kender en række af hans melodier, stammer bekendtskabet sikkert især fra folkekære stykker som Hostrups Gjenboerne (1844). Forskningen har omhyggeligt kortlagt Bellman-påvirkningen i dansk litteratur ${ }^{18}$, og her kan man søge detaljerede oplysninger om tiden efter Heibergerne.

Bellmans fortsatte popularitet langt ind $\mathrm{i}$ romantikkens periode og hos præster som Hostrup skyldtes også skandinavismen, som var udtryk for nordboernes stigende interesse for deres egen kultur. Til Bellman-festen i „Det scandinaviske Selskab“ i 1843 skrev Heiberg hyldestforedraget „Bellman, som comisk Dithyrambiker". Her understregede han atter, hvad han altid havde betragtet som det centrale i Bellmans kunst, nemlig den intime forening af ord og musik.

Han afslutter sit foredrag med at beklage, at man ikke i ord kan beskrive en digter, hvis kunst hænger så nøje sammen med hans musik. Derfor, skriver han, vil han nu tie og overlade det til „de bellmanske Sanges levende Foredrag at være Fredman den eneste Tolk"19. Vi bør naturligvis følge Heibergs eksempel og især lytte til de sange, der er lige så friske og levende som for 200 år siden. 
Noter

0 Birket-Smith 1928, s. 290.

1 Schoning 1904 , s. 37.

2 Ingerslev-Jensen, s. 157.

3 Refereret i Birket-Smith, s. 292.

4 I Dansk Litteratur Historie II, s. 451. Kilden til denne oplysning har det ikke været mig muligt at identificere, og ingen af de øvrige forfattere, jeg har konsulteret knytter Bellmans navn til familien Buntzen. Jeg viderebringer Friis' mening, fordi den forekommer mig sandsynlig, men jeg kan ikke anse den for dokumenteret.

5 Thalbitzer 1906, s. 92.

6 Thalbitzer 1906, s. 93.

7 Johanne Luise Heiberg 1882, I s. 51.

8 Jeg skal pointere, at denne antagelse ikke kan dokumenteres. Johanne Luise Heiberg nævner ikke Bellman i sin bog om svigerforældrene, ligesom Bellmans navn heller ikke er nævnt i den store korrespondance mellem parterne i det komplicerede kærlighedsforhold, som optrykkes i bogen (jvnf. navneregisteret til Johanne Luise Heiberg 1882, bd. II). Denne eventuelle udeladelse er påfaldende, eftersom fru Heiberg selv var en ivrig dyrker af Bellman og vel kunne tænkes at have bemærket det, hvis svigermoderen skulle have nævnt, at hun havde spillet Bell-

\section{Litteratur}

Bellman, Carl Michael (1790): Fredmans Epistlar, udg. af G. Hillbom og J. Massengale. tShlm. 1990.

Birket-Smith, Frederik (1928): „Bellman og Danmark“ i: Ord \& Bild 37. årg., s. 289-306 og 357-371.

Borup, Morten (1947-49): Johan Ludvig Heiberg I-III.

Dansk Litteratur Historie II. 1965.

Gyllembourg, Thomasine (1828): „En HverdagsHistorie“ i: Skrifter. 1849.

(1835): Ægtestand i: Skrifter III. 1849.

Heiberg, Johan Ludvig (1826): „Om Vaudevillen som dramatisk Digtart" i: Prosaiske Skrifter VI, s. 1-111. 1861.

- (1843): „Bellman, som comisk Dithyrambiker" i: Prosaiske Skrifter V, s. 39-64. 1861. man som ung. På den anden side skrev fru Heiberg det første udkast til bogen i 1858 , altså 65 år efter de nævnte musikalske scener havde fundet sted, og hun skrev den for at forsvare sin svigermor mod anklager for erotisk letsindighed. På de mange års afstand og emnets alvor taget i betragtning kan det have forekommet hende for bagatelagtigt at nævne, hvilke kunstnere de elskende dyrkede.

9 Gyllembourg 1835, s. 50.

10 Bellman 1790, s. 112.

11 Gyllembourg 1828, s. 22.

12 Trods de mange spor af musiceren á la Bellman i Gyllembourgs forfatterskab, skal jeg understrege, at jeg ikke har fundet Bellmans navn nævnt i nogen af hendes værker.

13 Hauch: Minder fra min forste Udenlandsreise (1871). Her citeret efter Borup 1947-49, s. I, 123.

14 Citeret efter Borup 1947-49, s. II, 43.

15 Om Vaudevillen som dramatisk Digtart (1826), citeret efter Prosaiske Skrifter VI, 1861, s. 106.

16 Johanne Luise Heiberg 1891, s. I, 157.

17 Hertz 1833.

18 Især Karl Warburg 1895, O. Schoning 1904 , Fr. Birket-Smith 1928 og Torben Krogh 1942.

19 Heiberg 1843, s. 64.

Heiberg, Johanne Luise (1882): Peter Andreas Heiberg og Thomasine Gyllembourg, 4. udg. vedAasge Friis og Just Rahbek I-II. 1947.

- (1891-92): Et Liv, gjenoplevet i Erindringen, 4. udg. ved Aage Friis m.fl. I-I. 1944.

Hertz, Henrik (1833): „Erindringer fra Hirschholm" i: Foraarets Nytaarsgave.

Ingerslev-Jensen, Povl (1974): P.A. Heiberg.

Krogh, Torben (1942): Heibergs Vaudeviller.

Schoning, O. (1904): Bellmans Digtning og dens Indflydelse i Danmark, i serien Studier fra Sprog-og Oldtidsforskningen nr. 63. 1904.

Thalbitzer, Sophie (1906): „Grandmamas Bekieldelser" i: J. Clausen og F. Riist (udg.): Memoirer og Breve IV.

Warburg, Karl (1895): „Bellmandikten i Danmark" i: Samlaren 16. årg., Uppsala. 